Vol. 5 No. 4 (2021) pp. 407- 416

Available online at: http://jurnal.umpwr.ac.id/index.php/abdimas/index

p-ISSN: $\underline{2580-3492}$ e-ISSN: $\underline{2581-0162}$

\title{
Pemberdayaan Warga Panti Asuhan di Bidang Pertanian Dalam Upaya Meningkatkan Perekonomian Melalui Budidaya Tanaman Herbal Andrograpis Paniculata
}

\section{Shafora Nurmala Devi $\bowtie$, Aisyiah, Much Firman Nasirudin, Zaenal Robidin, Ade Septiyo, Didik Widiyantono}

Universitas Muhammadiyah Purworejo

Jl. K.H.A. Dahlan 3 Purworejo,54111, Jawa Tengah, Indonesia

| shaforanurmala@gmail.com $ه$ | DOI : https://doi.org/10.37729/abdimas.v5i4.1304 |

\begin{abstract}
Abstrak
Pergeseran pola hidup di dalam masyaratak yang saat ini cenderung back to nature menyebabkan semakin meningkatnya permintaan obat herbal organik. Namun demikian, budidaya tanaman herbal secara organik masih jarang dilakukan. Pengabdian masyarakat ini bertujuan untuk Warga panti asuhan memperoleh keterampilan dan pengetahuan baru tentang peluang usaha tanaman hernal sambiloto (Andrograpis Paniculata) serta mengembangkan rumah bibit herbal organik yang berfungsi sebagai area pembibitan tanaman herbal dan meningkatkan minat generasi milenial dalam sektor pertanian. Pengabdian masyarakat dilakukan bersama Panti Asuhan Yatim Dhuafa Kaligesing, Purworejo. Perlunya pemberdayaan anak-anak panti asuhan menuju kemandirian melalui wirausaha menjadi alasan terselenggaranya kegiatan pengabdian ini. Adapun metode yang dilakukan berupa workshop dan pelatihan. Diharapkan dengan adanya kegiatan ini, partisispasi petani milenial terhadap pengembangan budidaya herbal organik semakin meningkat dan dapat meningkatkan taraf ekonomi warga panti asuhan.

Kata Kunci: Panti asuhan, Pertanian, Sambiloto
\end{abstract}

cc) (7) (8) This work is licensed under a Creative Commons Attribution-NonCommercial 4.0 International License

\section{Pendahuluan}

Salah satu permasalahan utama sumber daya manusia (SDM) pada sektor pertanian adalah rendahnya produktivitas tenaga kerja. Berdasarkan perhitungan menggunakan data BPS (2020a, 2020b), diketahui bahwa kuartel III tahun 2019 produktivitas tenaga kerja di sektor pertanian merupakan yang terendah di bandingkan sektor lainnya, yaitu sebesar Rp 10,7 juta per orang, nilai yang masih di bawah rata-rata produktivitas tenaga kerja nasional yang sebesar Rp21,3 juta per orang. Situasi sering terjadi di negara berkembang (Rani \& Roy 2017).

Dominannya sektor pertanian pada struktur tenaga kerja tidak diimbangi dengan kualitas SDM di dalamnya. Sektor pertanian didominasi golongan tua dengan tingkat pendidikan yang rendah. Lebih dari $65 \%$ kepala keluarga rumah tangga usaha pertanian (KK RTUP) berusia lebih dari 45 tahun (BPS 2018). Di sisi lain, regenerasi petani merupakan isu lama yang belum dapat diselesaikan oleh Kementerian Pertanian. Pandemi Covid-19 semakin memperparah situasi ini karena minat generasi muda untuk bekerja di sektor pertanian semakin berkurang (Kemen PPPA \& BPS 2018). 
Kemen PPPA dan BPS menyampaikan pendapat para ahli di mana generasi milenial yang disebut juga sebagai generasi $Y$ adalah penduduk yang lahir pada rentang waktu 1980-2000. Pendapat lain juga menyatakan hal yang serupa, yaitu generasi milenial lahir pada periode waktu 1980-2001 (Berkup 2014), 1980-1995 (Andrea et al. 2016), dan peneliti Indonesia pun menyatakan hal serupa, yaitu 1981-2000 (Ali \& Purwandi 2017). Meskipun waktu lahir menjadi variabel utama, kesamaan situasi sosial merupakan variabel yang mendasari pembagian waktu tersebut.

Generasi milenial tumbuh bersamaan dengan perkembangan teknologi informasi. Pada saat generasi milenial berada pada usia remaja, teknologi informasi berkembang sangat pesat. Dengan latar situasi teknologi seperti itu, generasi milenial memiliki ciri kreatif, inovatif, memiliki passion, dan produktif (Kemen PPPA \& BPS 2018). Generasi ini melibatkan teknologi dalam segala aspek kehidupan (Papp \& Matulich 2011). Dengan demikian, generasi milenial sangat dinamis dan ingin serba cepat dalam merealisasikan sesuatu. Di sisi lain, generasi ini juga terbuka terhadap pemikiran baru (open minded), kritis, dan berani. Oleh karena itu, generasi milenial dapat menciptakan peluang baru seiring dengan perkembangan teknologi yang semakin mutakhir.

Pola pertanian organik saat ini memiliki perkembangan yang sangat menjanjikan. Hal ini dikarenakan adanya pergeseran pola hidup di dalam masyarakat yang saat ini cenderung back to nature (Rosita, 2007). Meskipun demikian, pengelolaan budidaya tanaman obat secara organik masih belum banyak dikembangkan di Indonesia. Selain itu, sebagian besar suplai produksi tanaman obat tidak didapat dari hasil budidaya yang dikelola secara professional. Hal ini berakibat pada kurangnya pasokan bibit unggul tanaman obat. Oleh karena itu, pengembangan kebun bibit tanaman obat secara organik sebagai sarana pembelajaran bagi masyarakat di kota Purworejo sangat penting diimplementasikan.

Sebagian organ atau keseluruhan bagian tanaman obat dapat dimanfaatkan sebagai bahan baku pembuatan obat tradisional atau jamu. Beberapa penelitian mengungkapkan bahwa spesies tanaman obat ini memiliki aktivitas antibakteri (Hossan et al, 2018), antivirus (Mukhtar et al, 2008), immunomodulator (Wen et al, 2012), anti kanker (Greenwall \& Rahman, 2015), antioksidan (Jadid et al, 2018). Pada dasarnya, pengetahuan pemanfaatan tanaman sebagai obat tradisional telah dimiliki dan digunakan secara turun temurun oleh penduduk Indonesia, utamanya masyarakat rural. Namun demikian, dokumentasi metode pemanfaatan serta budidaya tanaman obat ini masih sangat terbatas pada beberapa orang saja (tetua adat atau sesepuh desa) (Jadid et al, 2020). Di sisi yang lain, ragam manfaat tanaman obat di dunia medis ini membuat komersialisasi tanaman obat terus mengalami peningkatan. Oleh karena itu, pengembangan sarana belajar alam bagi masyarakat mengenai manfaat dan pola budidaya tanaman obat sangat penting dilakukan.

Masyarakat yang menjadi mitra adalah warga Panti Asuhan Yatim Dhuafa yang terletak di desa Kaliharjo, kecamatan Kaligesing, kabupaten Purworejo. Warga panti asuhan ini berjumlah 55 orang yang terdiri dari 15 anak di usia dini, 30 anak remaja dan dewasa, terdiri dari laki-laki berjumlah 28 orang, perempuan berjumlah 17 orang, 8 orang anggota pengurus dan ketua mitra. Mayoritas anak-anak panti asuhan sudah memasuki usia 17 tahun ke atas dan perlu memulai belajar berwirausaha untuk melatih kemandirian. Panti asuhan yang terletak di desa ini belum memiliki kegiatan rutin yang bersifat menambah pemasukan dana panti, sehingga perekonomian untuk memenuhi kebutuhan sehari-hari hanya mengandalkan dana dari donatur. Oleh sebab itu, warga panti asuhan sangat membutuhkan pendampingan dalam peningkatan 
ekonomi terutama untuk menambah sumber pendapatan. Salah satunya dengan berwirausaha mandiri yang tidak membutuhkan biaya besar. Pemanfaatan tanah pekarangan yang kosong di panti asuhan, dapat dilakukan kegiatan berwirausaha melalui tanaman herbal pembibitan sambiloto yang merupakan cara efektif dalam berwirausaha mandiri. Selain tidak memerlukan biaya besar, pembibitan sambiloto ini sangat mudah dan praktis untuk diajarkan kepada warga panti asuhan. Selain mendapat penghasilan tambahan, warga panti juga memperoleh pengetahuan baru dalam berwirausaha mandiri dengan pembibitan sambiloto.

Pada umumnya sambiloto banyak tumbuh liar di hutan, namun sambiloto yang liar ini tidak efektif untuk diolah karena memiliki kadar mutu yang rendah sehingga sangat perlu dilakukan pembibitan untuk menghasilkan mutu terbaik yang dapat digunakan untuk obat herbal. Pembibitan tanaman sambiloto dipilih untuk peningkatan ekonomi panti asuhan yatim dhuafa karena tanaman ini memiliki peluang menjadi tren obat herbal dalam pengobatan Covid di Indonesia maupun di luar negeri (CNBN Indonesia, 2021). Mentri Riset dan Teknologi Bambang Brodjonegoro mengatakan bahwa pemerintah Indonesia mau mengikuti jejak Thailand terkait dengan keefektifan sambiloto sebagai suplemen spesifik untuk Covid-19, namun masih menunggu BPOM agar dapat segera mengambil keputusan dan membantu upaya pencegahan Covid-19. Kepala Balitbangtan, Kementrian Pertanian Fajry Djhufi mengatakan Balitbangtan melalui Balitro telah menyiapkan berbagai inovasi teknologi dalam mendukung pengembangan tanaman obat, salah satunya adalah tanaman sambiloto. Tanaman sambiloto memiliki prospek penjualan yang cukup tinggi, karena memiliki banyak manfaat untuk mengatasi berbagai penyakit bahkan di beberapa negara maju, tanaman ini sudah berkembang menjadi bahan baku obat. Adapun senyawa utama yang dihasilkan tanaman sambiloto adalah andrografolid, yang bermanfaat mengatasi berbagai penyakit antara lain sel kanker dan antitumor, anti hepatoprotektif, anti imflamasi, antoksidan, anti diabetes (menurunkan gula darah), anti malaria, dan anti microb (anti bakteri, anti fungi, anti firal). Menurut peneliti yang bertugas di Balai Penelitian Tanaman Rempah dan Obat (BALITRO), Bogor, senyawa andrografolid tersebut terdapat di dalam bagian atas jaringan tanaman yaitu daun, batang, bunga dan kandungan tertinggi terdapat pada daun. Daun sambiloto ini dapat diolah menjadi berbagai macam produk kesehatan. Hal tersebut tentu menjadikan sambiloto memiliki peluang besar dalam berwirausaha khususnya untuk peningkatan ekonomi warga panti asuhan.

Manfaat dari kegiatan progam pengabdian ini meliputi : kegiatan pengabdian ini dapat menumbuhkan empati dan kemampuan warga panti dalam mencari solusi permasalahan di masyarakat, warga panti asuhan memperoleh keterampilan dan pengetahuan baru tentang peluang usaha pembibitan sambiloto, warga panti asuhan mempunyai kegiatan untuk menambah penghasilannya.

Berdasarkan fakta yang telah dipaparkan di atas, ditemukan potensi untuk melakukan pemberdayaan warga panti asuhan terkait bidang ekonomi. Pemberdayaan warga panti asuhan tersebut dilakukan melalui progam pemberdayaan warga panti asuhan di bidang pertanian dalam upaya meningkatkan perekonomian melalui budidaya tanaman herbal andrograpis paniculat. 


\section{Metode}

Kegiatan ini merupakan rangkaian kegiatan pengabdian kepada masyarakat yang diselenggarakan melalui Program Kreativitas Mahasiswa Pengabdian Masyarakat, Universitas Muhammadiyah Purworejo yang di selenggarakan di desa Kaliharjo, Kecamatan Kaligesing, Kabupaten Purworejo pada bulan Juni-September 2021. Mitra dalam program ini adalah perwakilan pengurus dan sebagian dari anakanak Panti Asuhan Yatim Dhuafa sejumlah 30 orang.

Metode kegiatan pengabdian kepada masyarakat dalam bentuk workshop dan pelatihan. Tahapan pelaksanaan program pemberdayaan di desa Kaliharjo, di meliputi:

\subsection{Workshop}

Workshop ini terdiri dari persiapan yang dilakukan supaya pelaksanaan kegiatan berjalan dengan lancar sesuai yang diharapkan. Persiapan yang dilakukan oleh tim PKM terdiri dari rapat anggota, rapat koordinasi, survey lokasi dan kerjasama mitra yang bertujuan untuk mengumpulkan informasi awal tentang warga panti asuhan khususnya anak-anak panti yang akan diikutsertakan dalam program ini. Kemudian sosialisasi dilakukan dengan cara memberikan penjelasan dan pemahaman singkat kepada anak-anak panti asuhan untuk mengembangkan kreativitas para petani milenial guna meningkatkan perekonomian dalam sektor pertanian melalui budidaya tanaman herbal organik yaitu sambiloto. Materi terkait pemasaran tanaman herbal dan analisis usaha tani. Tim pengabdian kepada masyarakat menjelaskan dan menunjukkan tahapan teknik budidaya tanaman herbal organik sambiloto dan pembuatan rumah bibit herbal organik.

\subsection{Pelatihan}

Kegiatan pelatihan ini bertujuan untuk memberikan ketrampilan bagi anak-anak panti asuhan. Kegiatan praktik dalam budidaya tanaman herbal sambiloto terdiri dari pembuatan rumah bibit herbal, proses penyemaian sampai pemanenan, pemeliharaan dan pemasaran yang secara langsung di dampingi oleh tim pengabdian.

2.2.1. Analisis Usaha Tani

Analisis usaha tani dilakukan untuk mengetahui kelayakan usaha, beberapa hal yang dibahas dalam analisi ini adalah:

1) Biaya tetap; Biaya tetap memiliki karakteristik sebagai berikut :

a) Biaya yang jumlah totalnya tetap konstan tidak dipengaruhi oleh perubahan volume kegiatan atau aktifitas sampai dengan tingkat tertentu.

b) Pada biaya tetap, biaya satuan (unit cost) akan berubah berbanding terbalik dengan perubahan volume penjualan, semakin tinggi volume kegiatan semakin rendah biaya satuan.

2) Biaya variabel; Biaya tetap memiliki karakteristik sebagai berikut:

a) Biaya yang jumlah totalnya akan berubah secara serbandig (proporsional) dengan perubahan volume kegiatan, semakin besar volume kegiatan semakin tinggi jumlah total biaya variabel, semakin rendah volume kegiatan semakin rendah jumlah biaya variabel.

b) Pada biaya variabel, biaya satuan tidak dipengaruhi oleh volume kegiatan, jadi biaya semakin konstan 


\section{3) Penerimaan}

Menurut Soekarwati (2006) penerimaan adalah perkalian antara jumlah produk dengan harga jual produk per unit. Pada pasar persaingan sempurna, total penerimaan merupakan garis lurus dari titik origin, harga yang terjadi merupakan suatu yang tidak bisa dipengaruhi, maka penerimaan naik sebanding dengan jumlah barang yang dijual. Secara matematis dapat ditulis pada (1):

keterangan:

$$
T R=Q \times P q
$$

$$
\begin{array}{ll}
\mathrm{TR} & =\text { total penerimaan } \\
\mathrm{Q} & =\text { jumlah produksi } \\
\mathrm{Pq} & =\text { Harga produk }
\end{array}
$$

4) Keuntungan

Keuntungan adalah selisih lebih pendapatan atas beban sehubungan dengan kegiatan usaha. Apabila beban lebih besar dari pendapatan, selisih disebut rugi. Keuntungan atau kerugian merupakan hasil dari perhitungan berkala. Hal ini akan diketahui secara pasti saat perusahaan menghentikan kegiatannya dan dilakukan likuidasi (Soemarso, 2005).

5) Perhitungan Break Even Point (BEP)

a) BEP atas dasar unit

$$
B E P(Q)=F C / P-V C
$$

keterangan :

$\mathrm{BEP}=$ volume penjualan pada bep dalam unit

FC = biaya tetap

$\mathrm{P} \quad=$ harga jual produk per unit

$\mathrm{VC}=$ biaya variabel per unit

$\mathrm{P}-\mathrm{VC}=$ contribution margin

BEP atas dasar unit menunjukan penjualan yang harus dicapai untuk menghindari kerugian. Sedangkan contibutin margin/margin kontribusi menunjukan hasil penjualan yang tersedia untuk menutup semua biaya tetap

b) BEP atas dasar penjualan dalam rupiah

$\mathrm{FC}=$ biaya tetap

$\mathrm{VC}=$ biaya variabel

$S=$ volume penjualan $x$ harga jual per unit

$\mathrm{BEP}$ atas dasar penjualan menunjukan besarnya penerimaan minimal yang harus dicapai dari hasil penjualan untuk mencapai keadaan impas dan mampu menutup semua biaya. Rasio marjin kontribusi merupakan rasio dari marjin kontribusi terhadap hargapenjualan.

2.2.2. $\mathrm{R} / \mathrm{C}$ ratio

$\mathrm{R} / \mathrm{C}$ ratio merupakan ukuran perbandingan antara penerimaan dengan biaya operasional. $\mathrm{R} / \mathrm{C}$ ratio dihitung untuk menentukan kelayakan suatu usaha. $\mathrm{R} / \mathrm{C}$ ratio lebih dari satu maka usaha ini layak untuk dijalankan.

\subsection{3. $\mathrm{B} / \mathrm{C}$ ratio}

$\mathrm{B} / \mathrm{C}$ ratio biasanya digunakan untuk mengukur kelayakan suatu usaha tani dilihat dari keuntungan yang diperoleh yaitu dengan cara membandingkan antara keuntungan dengan total biaya yang dikelurkaan. B/C ratio lebih dari satu maka usaha ini berarti untung dan layak untuk dijalankan. 


\subsection{Pendampingan Iptek dan Evaluasi.}

Pendampingan yang dilakukan dalam pengabdian ini adalah pembentukan komunitas usaha budidaya tanaman herbal organik sambiloto, konsultasi dan monitoring melalui media sosial dan pengembangan mandiri. Evaluasi bertujuan untuk menilai dan memperbaiki pelaksanaan program yang sedang berjalan

\section{Hasil dan Pembahasan}

Hasil pelaksanaan program "Pemberdayaan Warga Panti Asuhan di Bidang Pertanian Dalam Upaya Meningkatkan Perekonomian Melalui Budidaya Tanaman Herbal Andrograpis Paniculat" merupakan hasil dan perwujudan perjanjian kerjasama tim pengabdian dan mitra Dokumen kerjasama tersebut antara lain tentang peran mitra dalam pelaksanaan ini. Adapun peran mitra adalah memfasilitasi kegiatan sosialisasi dan pelatihan, sanggup menindaklanjuti dan mengembangkan hasil program. Kesepakatan kerjasama mitra ditunjukkan pada Gambar 1.

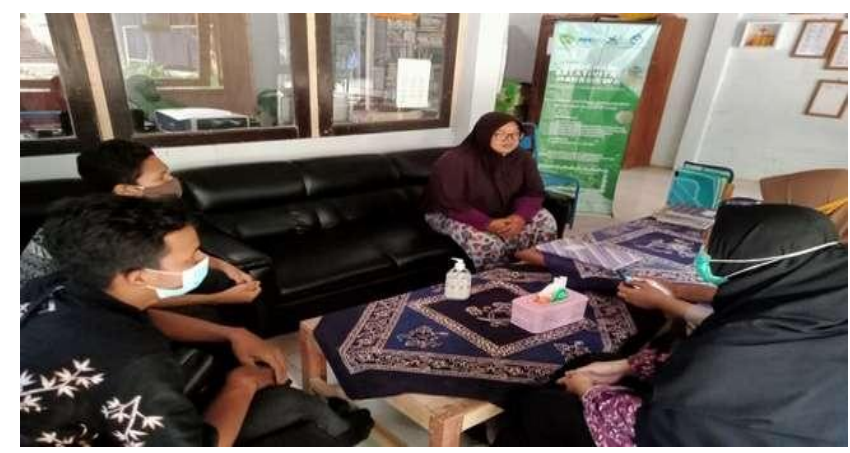

Gambar 1. Kesepakatan kerjasama mitra

Pelaksanaan sosialisasi program pemberdayaan warga panti asuhan di bidang pertanian dalam upaya meningkatkan perekonomian melalui budidaya tanaman herbal andrograpis paniculat dilaksanakan selama 1 kali yaitu pada tanggal 10 juni 2021 di musola Panti Asuhan Yatim Dhuafa Kaligesing, Purworejo. Sosialisasi ini bertujuan untuk memberikan dasar pemahaman dan pengetahuan mengenai teknik budidaya tanaman herbal organik sambiloto karena belum banyak warga panti asuhan yang mengetahuinya. Sosialisasi dapat ditunjukkan pada Gambar 2.

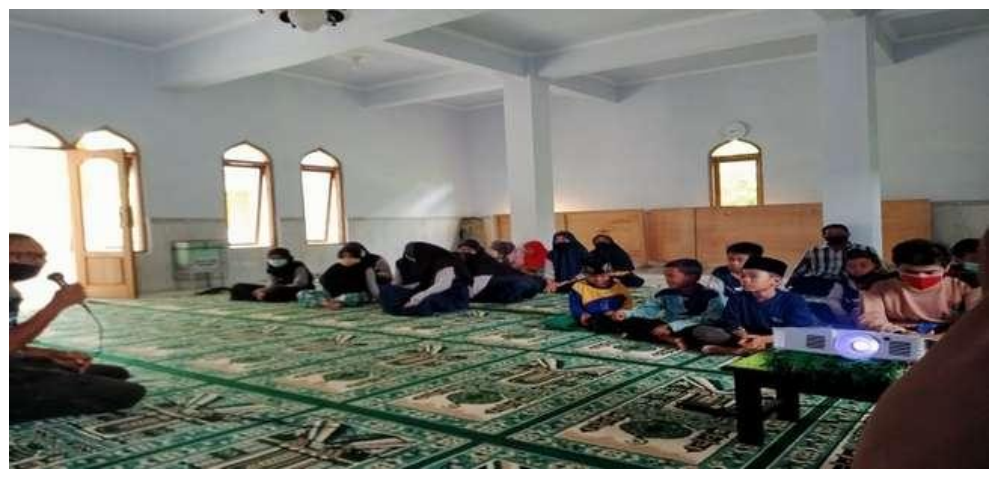

Gambar 2. Sosialisasi program ke mitra 
Pelaksanaan kegiatan pelatihan proses pembuatan rumah bibit herbal dan penyemaian benih sambiloto dilaksanakan sejak tanggal 18 juni sampai 8 juli 2021 . Bibit benih akan ditempatkan pada rumah bibit seperti Gambar 3.

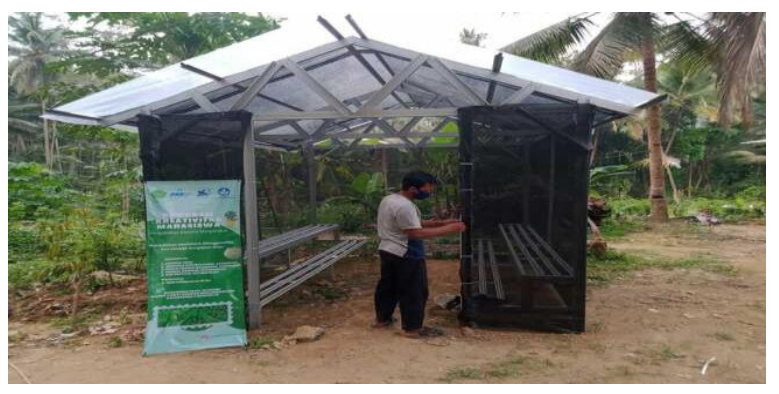

Gambar 3. Rumah bibit Sambiloto

Analisis usaha tani tanaman herbal organik sambiloto pada pemanfaatan potensi panti asuhan. Perkiraan analisis usaha tani budidaya sambiloto dengan populasi tanaman sebanyak 1000 benih sambiloto selama 3 bulan. Terdapat penjelasan pada Tabel 1 dan Tabel 2.

Tabel 1. Biaya Tetap budidaya tanaman sambiloto (Andrograpis paniculata)

\begin{tabular}{llccc} 
No & Uraian & Kebutuhan & Harga Satuan & Masa Pakai (bulan) \\
1 & Cangkul & 1 buah & $\operatorname{Rp~} 70.000$ & 36 \\
2 & Gembor & 2 buah & $\operatorname{Rp} 35.000$ & 36 \\
3 & Ember & 2 buah & $\operatorname{Rp} 15.000$ & 36 \\
4 & Pisau & 2 buah & $\operatorname{Rp} 10.000$ & 12 \\
5 & Gunting Stek & 2 buah & $\operatorname{Rp} 20.000$ & 24 \\
6 & Hand spayer & 2 buah & $\operatorname{Rp} 35.000$ & 12 \\
7 & Bambu & 5 buah & $\operatorname{Rp} 5.000$ & 6 \\
8 & Nampan & 5 buah & $\operatorname{Rp~} 7.000$ & 36 \\
9 & Plastik & 6 meter & $\operatorname{Rp} 3.000$ & 9 \\
10 & Tali & $0,5 \mathrm{~kg}$ & $\operatorname{Rp} 12.000$ & 3 \\
\hline
\end{tabular}

Apabila semua bibit tanaman sambiloto telah terjual akan diperoleh keuntungan sebesar Rp. 3.500.000. Keuntungan diperoleh dari hasil perhitungan penjualan benih tanaman sambiloto dengan prosentase yang hidup sebesar $70 \%$ dari 1000 tanaman. Harga jual bibit sambiloto per polibag kecil adalah Rp 5.000,00. R/C Ratio (Revenue / cost ratio) atau nilai kelayakan usaha tani merupakan ukuran perbandingan antara penerimaan dengan total biaya operasional. Sedangkan B/C Ratio (Benefit / cost ratio) atau nilai keuntungan usaha tani merupakan ukuran perbandingan antara keuntungan dan total biaya operasional.

Suatu usaha dapat dikatakan layak dan untung dikembangkan apabila nilai revenue $\operatorname{cost}(\mathrm{R} / \mathrm{C}$ ratio) dan benefit cost (B/C ratio) masing-masing hasilnya lebih dari satu. Dari analisis biaya tersebut diperoleh nilai R/C Ratio sebesar 3,25 sedangkan untuk B/C Ratio sebesar 2,25. Jadi semakin tinggi R/C Ratio maka berakibat semakin tinggi pula penerimaan yang diperoleh dan semakin tinggi B/C Ratio maka berakibat semakin tinggi pula keuntungan yang diterima. 
Tabel 2. Biaya variabel budidaya tanaman sambiloto (Andrograpis paniculata)

\begin{tabular}{|c|c|c|}
\hline No & Uraian & Kebutuhan \\
\hline 1 & Benih & 1,5 gram \\
\hline \multirow[t]{8}{*}{2} & Pupuk: & \\
\hline & - SAN & $1 \mathrm{~kg}$ \\
\hline & - SNN & $1 \mathrm{~kg}$ \\
\hline & - SP-36 & $1,5 \mathrm{~kg}$ \\
\hline & - Kcl & $1,5 \mathrm{~kg}$ \\
\hline & - NPK & $1,5 \mathrm{~kg}$ \\
\hline & - Pembenah tanah & 50 gram \\
\hline & - Asbun & 50 gram \\
\hline 3 & Dolomit & $0,5 \mathrm{~kg}$ \\
\hline 4 & Polybag & $4 \mathrm{~kg}$ \\
\hline \multirow[t]{4}{*}{5} & Tenaga Kerja & $1 \mathrm{HKP}$ \\
\hline & Pembibitan ( 1 hari) & \\
\hline & Persiapan lahan (2 hari) & \\
\hline & Pemeliharaan ( 3 bulan) & \\
\hline
\end{tabular}

Publikasi kegiatan ini sebagai bentuk transfer ilmu dan teknologi dilakukan secara daring melalui jejaring sosial seperti instagram https://www.instagram.com/ pembibitan.sambiloto_pwr/ , website kemahasiswaa http://umpwr.ac.id/index.php /detail/detail_news/110, dan purworejo44 https://www.purworejo24.com/2021/ 06/ump-raih-dana-hibah-kemendikbud-untuk-pembibitan-sambiloto-menggunakanpot-limbah-gergajian -kayu/ . Publikasi tersebut ditunjukkan pada Gambar 4.

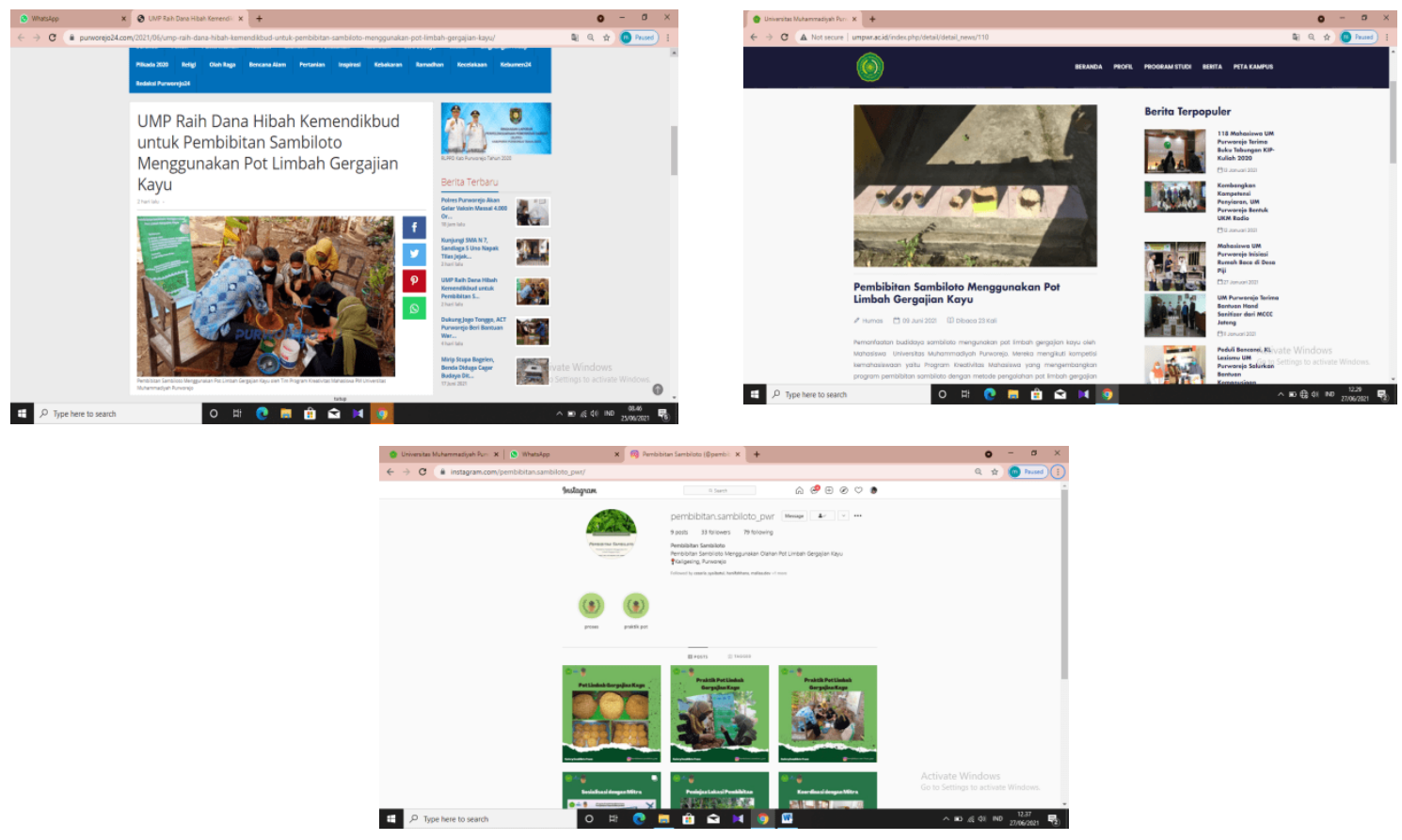

Gambar 4. Publikasi kegiatan pengbdian masyarakat 


\section{Kesimpulan}

Berdasarkan hasil pelaksanaan Program Kreativitas Mahasiswa Bidang Pengabdian Masyarakat pembangunan pertanian untuk meningkatkan kesejahteraan warga panti asuhan, diperoleh hasil bahwa warga panti asuhan Kaligesing memperoleh pengetahuan dan keterambilan mengenai budidaya dan pemeliharaan tanaman herbal organik sambiloto. Implementasi kegiatan yang merupakan solusi dari setiap permasalahan mitra dilaksanakan secara bertahap dan sistematis sehingga permasalah yang dihadapi oleh mitra dapat teratasi dengan baik. Model pemberdayaan masyarakat dengan melibatkan mitra dan pemangku kepentingan dapat dijadikan rekomendasi bagi permasalahan serupa sehingga masing-masing mitra akan mendapatkan manfaat dari kerja sama strategis ini. Panti Asuhan Yatim Dhuafa menjadi pelopor petani melenial untuk masa mendatang.

\section{Acknowledgement}

Tim pengabdian pada masyarakat mengucakan terima kasih kepada Belmawa Kemenristekdikti yang telah memberikan pendanaan untuk PKM pengabdian masyarakat. Ucapan terima kasih juga disampaikan kepada warga panti asuhan yatim dhuafa kaligesing sebagai mitra yang telah memfasilitas kegiatan pelatihan Budidaya Tanaman Herbal Andrograpis Paniculata untuk meningkatkan perekonomian warga panti asuhan.

\section{Daftar Pustaka}

Ali H, Purwandi L. 2017. The urban middle-class millenials Indonesia: financial and online behavior. Jakarta (ID): Alvara Strategi Indonesia.

Andrea B, Gabriella HC, Timea J. 2016. Y and Z generations at workplaces. J Compet. 8(3):90-106.

Badan POM RI. (2020). Pedoman penggunaan herbal dan suplemen kesehatan dalam menghadapi Covid-19 di Indonesia. BPOM Pusat Jakarta.

[BPS] Badan Pusat Statistik. 2018. Hasil survey pertanian antar sensus (Sutas) 2018. Jakarta (ID): Badan Pusat Statistik.

[BPS] Badan Pusat Statistik. 2020a. [Seri 2010] PDB seri 2010 (Milyaran Rupiah), 2020. [Interne]. [diunduh 2020 Okt 24]. Tersedia pada : Https:/ / bps.go.id/inicator/11/65/1/-seri-2010-pdb-seri-2010.html.

[BPS] Badan Pusat Statistik. 2020b. Perkembangan beberapa indikator utama socialekonomi Indonesia. Jakarta (ID) : Badan Pusat Stastik.

Berkup SB. 2014. Working with generations $\mathrm{X}$ and $\mathrm{Y}$ in generation $\mathrm{Z}$ period: management of different generations in business life. Meditteranean J Soc Sci. 5(19): 218-229.

Greenwell, M., Rahman, PK. "Medicinal Plants: Their Use in Anticancer Treatment". International Journal of Pharmaceutical Sciences and Research 6, no. 10 (October 2015), 4103-4112. 
Hossan, MS., Jindal H., Maisha, S., Samudi Raju, C., Devi Sekaran S., Nissapatorn V., Kaharudin, F., Su Yi L., Khoo, TJ., Rahmatullah, M., Wiart, C. "Antibacterial effects of 18 medicinal plants used by the Khyang tribe in Bangladesh". Pharmaceutical Biolology 56, no. 1 (December 2018), 201-208.

Jadid, N., Arraniry, BA., Hidayati, D., Purwani, KI., Wikanta, W., Hartanti, SR., Rachman, RY. "Proximate composition, nutritional values and phytochemical screening of Piper retrofractum vahl. Fruits". Asian Pacific Journal of Tropical Biomedicine 8, no.1 (October 2018), 37-43.

Jadid, N., Kurniawan, E., Himayani, C., Andriyani, Prasetyowati, I., Purwani, K. I., Muslihatin, W., Hidayati, D., \& Tjahjaningrum, I. "An ethnobotanical study of medicinal plants used by the Tengger tribe in Ngadisari village, Indonesia". PloS one, 15 no. 7 (July 2020), e0235886.

Kemen PPPA dan BPS] Kementerian Pemberdayaan Perempuan dan Perlindungan Anak dan Badan Pusat Statistik. 2018. Profil generasi milenial Indonesia. Jakarta (ID): Kementerian Pemberdayaan Perempuan dan Perlindungan Anak.

Mukhtar, M., Arshad, M., Ahmad, M., Pomerantz, RJ., Wigdahl, B., Parveen, Z. "Antiviral potentials of medicinal plants". Virus Research 131, no. 2 (February 2008), 111-120.

Papp R, Matulich E. 2011. Negotiating the deal: using technologyto reach the millennials. J Behav Stud Bus.. 4(2011):1-12.

Rani A,Roy P. 2017. Youth in agriculture:role of goverment initiatives.J Agric Ext Manag. 18(2):167-175.

Rosita SMD. "Kesiapan Teknologi Mendukung Pertanian Organik Tanaman Obat: Kasus Jahe (Zingiber officinale Rosc.)". Perspektif 6, no. 2 (Desember 2007), 7584.

Soekarwati, 2006. Analisis Usahatani.Jakarta:UI-Press.

Soemarso. 2005. Akuntasi Suatu Pengantar. Edisi Revisi,Jakarta:Salemba. Empat.

Wen, CC., Chen, HM., Yang, NS. "Developing Phytocompounds from Medicinal Plants as Immunomodulators". Advance in Botanical Research 62 (Juni 2012), 197-272.

https://www.cnmindonesia.com/gaya-hidup/20210625183105-255-659556/ekstraksambiloto-disebut-bantu-penyembuhan-pasien-covid-19 